\title{
Quality of life and everyday mobility of schoolchildren: what choice do Moscow parents make?
}

\author{
Elena Nekhorosheva $^{1^{*}}$, Elena Alekseycheva ${ }^{2}$, and Anastasia Kravchenko ${ }^{1}$ \\ ${ }^{1}$ Moscow City University, Scientific Research Laboratory of Personal Development and Health \\ Protection, Moscow, Russia \\ ${ }^{2}$ Moscow City University, Department of Philosophy and Social Sciences, Moscow, Russia
}

\begin{abstract}
The educational space of a contemporary metropolis is characterized by broad diversity. Often, the choice of an educational institution that best meets the needs of the child and family is made in favor of a school that is at a distance from home, and the development of transport infrastructure makes this choice easier. Studies of children's daily mobility, the factors that determine them, and the quality of families' involvement in moving around the city to get an education are becoming quite relevant. The goal of the present research is to assess the significance to families with children of different ages of choosing a school within remote or walking distance and to describe the difficulties faced by parents. Methods included the authorial questionnaire, a sample of 414 parents of children studying in one of the administrative districts of Moscow. The basic results of the study can be formulated as follows. The topic of everyday educational mobility in the views of parents is relevant and significant for the city; the convenience of the school location is a key factor of choice; mobility increases as children grow up, with enlargement of schools, and the implementation of the "Big city schools" project which increases intraschool mobility; the average travel time to school is about 10 minutes on foot; for families whose children study in remote accessibility, the most important are vital topics of safety for the children's life and health, including lifestyle issues; developing programs for parents whose children walk to school, and families who use private vehicles requires a differentiated approach.
\end{abstract}

Keywords: children's everyday mobility, school choice, quality of life, intraschool mobility.

\section{Introduction}

Research interest in the everyday mobility of pupils in the city is associated, on the one hand, with the intensification of urban processes and growth of the educational services market [1], and on the other hand, with increased demands of families for unique quality educational services for preschool and school-age children [2]. In these conditions,

\footnotetext{
${ }^{*}$ Corresponding author: sjelene@yandex.ru
} 
everyday mobility is an integral part of the city's open educational space, which creates an opportunity for independent planning and implementation of the educational trajectory of the pupil and family [3], on the one hand, and on the other hand, sets before the city administration the task of competent urban planning for the distribution of a uniform load on schools [4].

The educational space of the city is diverse, and often the choice of a school that meets the needs of the child and family is carried out in favor of the school which is at a distance from home, while the development of transport infrastructure makes this choice easier. When families enroll their children in school, move from primary to secondary school, or choose specialized education, they choose a school based on the resources available to them. Some children go to a nearby school and get a full secondary education there, some children change their place of study at one stage or another, while some families even enroll their child in kindergarten in remote accessibility from home. The reasons for such choice may be different, but, as a rule, they are reduced to two criteria: territorial accessibility and quality of education.

An increase in the number of learning options results in a loosening of the link between place of residence and the quality of the nearby school [5]. Thus, the everyday mobility of preschool and school-age children becomes particularly relevant. Daily movements of children of different ages around the city caused by general education are carried out within the territories of interdistrict boards of directors [6], within and between administrative districts, as well as between the capital and the region.

The "new mobility" paradigm, extending and developing the "mobility turn" within the social sciences [7], has been forming over the past decade. With "mobility turn", one can go beyond institutional sociology and talk about everyday mobile practices described through the quality of presence and copresence, health [7], effective manifestations [8], and life stories that shape experiences and interpretations of the world [9].

Shifting the research focus on the individual and their inner world makes it possible to study the impact of urban mobility on a child's social, cognitive, and emotional development. Children who were accompanied to school by an adult performed cognitive tests in the same way as their unaccompanied peers but have shown greater tendency in the understanding of traffic hazards and better knowledge of the environment [10]. Differences in everyday mobility are associated with the child's age and academic performance [11].

Another issue is the impact of everyday mobility on children's health, their psychological well-being, and safety, as well as the relationship between transport travel and children's physical, psychological, cognitive, and social well-being [12, 13].

The everyday mobility and freedom of movement of children are closely linked to the position of parents or what the authors call the parental "mobility permit" or "mobility license" [14]. The factors that determine them are based on the perception of the safety of independent travel by parents [15], the experience of parents' safety [16], parental motives, and fears regarding independent mobility of girls and boys in the city [17], the negative relationship between distance to school and independent mobility of children, their active behavior during the trip [18].

The need for flexible and secure mobility in the metropolis is constantly growing. This phenomenon is inevitable and natural in connection with the implementation of the mission of a contemporary school - meeting the educational needs of pupils depending on their interests. Moscow schools are constantly working to ensure the variability of educational programs. On the one hand, this allows each pupil to personalize the educational process. On the other hand, if the place of residence is remote from the school, which, in the opinion of the family, can ensure the personal and pre-professional development of the child, the time spent by the child for the trip increases. This time is used neither for recreational nor for educational purposes and is associated with risks to the child's safety and health, 
increasing tension and anxiety of the parents. The tasks of using the city's resources for the child's socialization during their daily movements become quite urgent. This involves risk management, understanding and minimizing threats during independent movement of children; developing measures to reduce social tension; reducing parents' anxiety and improving children's safety; making infrastructural decisions for the city that would improve the quality of life of the population.

The research goal consists in assessing the significance for families with children of different ages of choosing a school within remote or walking distance and describing the difficulties faced by parents. The authors consider the remote availability of a school as the need to use personal or public transport to get an education.

\section{Methods}

The research is based on a survey of parents (n-414) living in the territory of interdistrict boards of directors No. 4 and No. 6 of the North-Eastern Administrative Okrug of Moscow, conducted in December of 2019. The authors used a specially developed questionnaire.

The socio-demographic profile of respondents was predominantly females $(89 \%)$ in the age range of 36-45 years (62\%), 26-35 years (20\%), 46-55 years $(16.2 \%)$, and parents under 25 and over 55 years of age (1\%). Respondent parents had about 800 children enrolled in educational institutions. Among them, 15\% were preschool children, $64 \%$ were studying at primary school, $37 \%$ were in grades $5-7,14.5 \%$ were in grades $8-9$, and a small number of children were of senior school age or students.

\section{Results}

Three-quarters of responses from Moscow parents allow asserting the relevance of the topic of everyday educational mobility. Thus, $76.9 \%$ of respondents noted the significance of the problem of teaching children not at the place of their residence, and $75.3 \%$ of respondents noted the importance of teaching children at the place of permanent residence.

More than half of the respondents $(55 \%)$ indicated the convenience of the school location as the first-choice factor. The quality of subject education as a decisive factor was noted by $51.3 \%$ of parents, while $39.4 \%$ of Moscow parents chose the school's rating.

The location of the school within the walking distance allows the child to comply with the regime, save time and efforts, and provides higher quality of life. The structure of the distribution of travel methods is shown in Table 1.

Table 1. Time spent by pupils on the way to school, $\%$.

\begin{tabular}{|l|c|c|c|c|c|}
\hline & $\begin{array}{c}\mathbf{5 - 1 5} \\
\text { minutes }\end{array}$ & $\begin{array}{c}\mathbf{1 5 - 2 5} \\
\text { minutes }\end{array}$ & $\begin{array}{c}\mathbf{2 5 - 4 5} \\
\text { minutes }\end{array}$ & $\begin{array}{c}\mathbf{4 5 - 6 0} \\
\text { minutes }\end{array}$ & $\begin{array}{c}\text { more than } \\
\text { an hour }\end{array}$ \\
\hline On foot on their own & 85.29 & 13.73 & 1.96 & 0.98 & 0.00 \\
\hline $\begin{array}{l}\text { On foot accompanied by an } \\
\text { adult }\end{array}$ & 77.66 & 19.15 & 2.13 & 2.13 & 0.00 \\
\hline $\begin{array}{l}\text { By public transport on their } \\
\text { own }\end{array}$ & 24.24 & 37.88 & 31.82 & 10.61 & 1.52 \\
\hline $\begin{array}{l}\text { By public transport } \\
\text { accompanied by an adult }\end{array}$ & 36.96 & 30.43 & 23.91 & 10.87 & 0.00 \\
\hline By parent's private transport & 46.67 & 44.76 & 9.52 & 0.95 & 0.95 \\
\hline
\end{tabular}


The data show that for children, walking on foot is the preferred way of going to/from the school, however as the travel time increases, the proportion of pupils using public transport increases as well. At that, the school that is within walking distance becomes remote.

Table 2 shows the age distribution of the significance of territorial accessibility.

Table 2. Age distribution of the significance of territorial accessibility, \%.

\begin{tabular}{|l|c|c|c|c|c|}
\hline & $\mathbf{1}$ & $\mathbf{2}$ & $\mathbf{3}$ & $\mathbf{4}$ & $\mathbf{5}$ \\
\hline Preschool age & 7.1 & 1.2 & 14.1 & 11.4 & 66.3 \\
\hline Elementary school & 8.4 & 2.3 & 18.0 & 14.6 & 56.7 \\
\hline Grades 5-7 of middle school & 10.3 & 7.6 & 27.1 & 20.2 & 34.7 \\
\hline Grades 8-9 of middle school & 15.6 & 12.9 & 27.7 & 19.1 & 24.6 \\
\hline Grades 10-11 of high school & 24.4 & 15.4 & 26.4 & 13.8 & 20.1 \\
\hline Additional education & 13.8 & 7.9 & 28.9 & 18.6 & 30.8 \\
\hline
\end{tabular}

This situation raises the question of the risks and difficulties faced by families in connection with the education of children in direct or remote accessibility of the educational institution (Table 3).

Table 3. Structure of family difficulties in connection with the education of children in case of remote accessibility of the school, $\%$.

\begin{tabular}{|l|c|c|c|}
\hline & Total sample & $\begin{array}{c}\text { Sample of } \\
\text { parents having } \\
\text { private } \\
\text { vehicles }\end{array}$ & $\begin{array}{c}\text { Sample of parents } \\
\text { whose children go } \\
\text { to school on foot }\end{array}$ \\
\hline $\begin{array}{l}\text { Difficulties in organizing the daily } \\
\text { routine }\end{array}$ & 40.5 & 35.2 & 50.5 \\
\hline $\begin{array}{l}\text { Insecurity due to large concentrations of } \\
\text { people in public transport }\end{array}$ & 51.3 & 37.1 & 52.5 \\
\hline Insecurity due to additional health risks & 43.1 & 38.1 & 43.6 \\
\hline Psycho-emotional stress & 36.1 & 30.5 & 36.6 \\
\hline Waste of time on the road & 42.4 & 41.0 & 38.6 \\
\hline $\begin{array}{l}\text { Reduced time spent communicating with } \\
\text { peers }\end{array}$ & 21.2 & 21.0 & 16.8 \\
\hline Physical load (heavy briefcase, etc.) & 42.8 & 32.4 & 42.6 \\
\hline Difficulties in catering & 21.9 & 18.2 & 27.7 \\
\hline Parents' worries and concerns & 47.6 & 37.1 & 54.5 \\
\hline $\begin{array}{l}\text { Problems with parking lots and } \\
\text { approaches to the school }\end{array}$ & 42.4 & 74.3 & 22.8 \\
\hline Irregular operation of public transport & 18.6 & 16.2 & 18.8 \\
\hline Lack of school buses & 34.6 & 34.3 & 35.6 \\
\hline $\begin{array}{l}\text { Uneven location of schools and school } \\
\text { buildings }\end{array}$ & 20.1 & 22.9 & 22.8 \\
\hline
\end{tabular}




\section{Discussion}

According to Bain \& Company [19], the main criteria for choosing a school in the world are the quality of education and the convenient location of the educational organization. In Moscow, the first place was taken by criterion, such as the convenience of the school location, the second place was taken by the education quality, and the third - by discipline, security, internal atmosphere, and psychological condition. According to the conducted survey, a slightly different response breakdown was obtained based on a variety of obtained factors. When families preferred in-depth knowledge, they confirmed the importance of the quality of successful schools which was manifested by meeting expectations concerning the curriculum, school culture, and general impressions when attending school [5].

More than half of the respondents' children spend between 5 and 15 minutes on the road to school, which corresponds to the outcomes of other researchers. Distance to school and children's age are the most influential variables determining the independent mobility of children.

The authors' hypothesis has been confirmed that the family had to make a key choice between the convenience of the school location and the quality of education in favor of convenience for quite vital reasons. Thus, $51.3 \%$ of respondents noted the importance of safety issues for the life and health of the child during the trip in public transport and relevant anxiety experiences of parents $(47.6 \%)$. In second place, there was a group of lifestyle-related factors that did not contribute to the child's health. These were physical and psycho-emotional loads, violations of the daily routine, including catering, reduction of time for live communication with loved ones, and reorientation to remote communication in social networks. The third block of difficulties lay in the area of transport infrastructure solutions: parking lots, school approaches, public transport services, etc. All the above highlights the key areas for improving the quality of social life in the city in terms of assisting families whose children participate in the daily transport life of the city as passengers [10].

The obtained data indicate the need for a differentiated approach to different families since parents whose children go to school on their own are characterized by high anxiety. Anxiety arises from a lack of trust and insufficient grounds to rely on a situation where the child remains out of the adult's control. This may be due to both the child's behavior and the unreliability of the urban environment. As it follows from Table 3, the difficulties of families bringing their children to school by car are related to road network management. Here, control over the child's movement is higher, so anxiety is lower [18].

\section{Conclusion}

Our results show significant differences in cognitive primary competencies of 5th-graders depending on the type of the educational media. We assume, that the "content-and-activity oriented" media provides for better results in terms of cognitive reflection, analysis, planning capacity, modelling skills.

"Knowledge oriented" media is aimed at acquisition and mastering skills to solve problems according to problem-types - thus, students may appear to be more sufficient in standard tests, than students from "activity-and-content oriented" educational media. But initial competencies, which are considered nowadays to be essential, are thus left unattended - though they still can be acquired due to personal students' (and their family's) efforts. At the same time providing complete and sound orientation basis is the basic principle for "activity-and-content oriented" educational media.

Moreover, whether a student has come upon adequate orientation or invents some "round-about" way cannot be diagnosed by usual written tests with the same typical tasks. 
But when students face new types of problems and new topics, those, who relied on "roundabout" ways, have to invent new techniques. With every step in education it becomes more difficult. Meanwhile, those students, who have acquired adequate orientation basis, are more likely to be sufficient when the circumstances change. They need to adjust the acquired means of orientation, but the circumstances do not appear totally new for them. And even if they do, the previous experience of conscious working mediated with cultural means, may help. These two aspects - general orientation basis for some domain and a general attitude to learning - comprise cognitive meta-subject results and need to be addressed in future studies.

Creating educational media that would scaffold formation of primary competencies is still a challenge and a beacon for educators, psychologists and curriculum designers. We assume, that "activity-and-content oriented" media, devised within the Developmental Instruction, is the first step in this direction.

\section{References}

1. E.Yu. Alekseycheva, E. V. Nekhorosheva, Vestnik of Moscow City University. Series: Pedagogy and Psychology, 52(2), 88-102 (2020). https://doi.org/10.25688/20769121.2020.52.2.09

2. S. Kosaretsky, et al., Russian school: the beginning of the XXI century (Higher School of Economics Publishing House, Moscow, 2019). https://doi.org/10.17323/978-575981955-4

3. G. Vecchio, Journal of Transport Geography, 83, 102652 (2020). https://doi.org/10.1016/j.jtrangeo.2020.102652

4. F.J. Jaraíz-Cabanillas, A.M. Hernández-Carretero, E.E. Ruiz-Labrador, J.A. GutiérrezGallego, Documents d'Analisi Geografica, 64 (1), 73-98 (2018). https://doi.org/10.5565/rev/dag.359

5. K.D. Hill, Improving Schools, 21(3), 209-224 (2018). https://doi.org/10.1177/1365480218783793

6. Order of Department of Education of Moscow of April 27, 2015, No. 190 “ $\mathrm{Ob}$ utverzhdenii tipovogo polozheniya o mezhrayonnom sovete direktorov gosudarstvennykh obrazovatel'nykh organizatsiy, podvedomstvennykh Departamentu obrazovaniya goroda Moskvy" ["On approval of standard provisions on the Board of Directors of the state educational institutions of the Department of Education of the city of Moscow"]

7. M. Sheller, J. Urry, Environment and Planning A: Economy and Space, 38(2), 207-226 (2006). ttps://doi.org/10.1068/a37268

8. N. Cass, J. Faulconbridge, Mobilities, 12(1), 97-115 (2017). https://doi.org/10.1080/17450101.2015.1096083

9. K. Doughty, L. Murray, Mobilities, 11 (2), 303-322 (2014). https://doi.org/10.1080/17450101.2014.941257

10. M.S. Joshi, M. MacLean, W. Carter, British Journal of Developmental Psychology, 17(1), 125-139 (1999). https://doi.org/10.1348/026151099165195

11. S. Anderson, Psychology in the Schools, 54(5), 487-503 (2017). https://doi.org/10.1002/pits.22010

12. K.Y.K. Leung, B.P.Y. Loo, Travel Behaviour and Society, 9, 95-104 (2017). https://doi.org/10.1016/j.tbs.2017.07.004 
13. E.O.D. Waygood, M. Friman, L.E. Olsson, A. Taniguch, Travel Behaviour and Society, 9, 32-49 (2017). https://doi.org/10.1016/j.tbs.2017.04.005

14. T. Joelsson, Children's Geographies. Routledge, 17(5), 591-602 (2019). https://doi.org/10.1080/14733285.2019.1582752

15. P. van den Berg, E.O.D. Waygood, I. van de Craats, A. Kemperman, Journal of Transport and Health, 16, 100837 (2020). https://doi.org/10.1016/j.jth.2020.100837

16. A. Fyhri, R. Hjorthol, Journal of Transport Geography, 17(5), 377-384 (2009). https://doi.org/10.1016/j.jtrangeo.2008.10.010

17. S. Foster, K. Villanueva, L. Wood, H. Christian, B. Giles-Corti, Health and Place, 26, 60-68 (2014). https://doi.org/10.1016/j.healthplace.2013.11.006

18. E.Y. Lin, K. Witten, M. Oliver, P. Carroll, L. Asiasiga, H. Badland, K. Parker, Health and Place, 46, 107-113 (2017). https://doi.org/10.1016/j.healthplace.2017.05.002

19. A. Panov, Moskovskoye Obrazovaniye: Povysheniye Effektivnosti Na Fone Global'nykh Peremen [Moscow Education: Increasing Efficiency Amid Global Change] (Bain Research, Moscow, 2018)

20. R. Dowling, Geoforum, 31(3), 345-353 (2000). https://doi.org/10.1016/S00167185(99)00048-2 